\title{
Isolation of Differentially Expressed Transcripts by cDNA-AFLP and Expression Analysis of DEAD Box ATP-Dependent RNA Helicase 48 in Ovaries of the Giant Tiger Shrimp Penaeus
}

\section{monodon}

\author{
Sirawut Klinbunga ${ }^{1}$, Sirikan Prasertlux ${ }^{1}$, Sirithorn Janpoom ${ }^{1}$, Puttawan \\ Romgmung ${ }^{1}$, Bavornlak Khamnamtong ${ }^{1, *}$ (i)
}

\begin{abstract}
${ }^{1}$ Aquatic Molecular Genetic and Biotechnology Team, National Center for Genetic Engineering and Biotechnology (BIOTEC), National Science and Technology Development Agency (NSTDA), 113 Paholyothin Road, Khlong Nueng, Khlong Luang, Pathum Thani 12120, Thailand
\end{abstract}

\section{Article History}

Received 16 June 2020

Accepted 09 September 2020

First Online 25 September 2020

\section{Corresponding Author}

Tel.: +6626448150

E-mail: bavornlak@biotec.or.th

\section{Keywords}

Penaeus monodon

Shrimp

Gene Expression

CDNA-AFLP

$D d \times 48$

\begin{abstract}
Genes involved in ovarian development of the giant tiger shrimp (Penaeus monodon) were isolated by cDNA-AFLP analysis. In total, 75 primer combinations were screened against cDNA of different stages of ovaries (premature ovaries of juveniles and previtellogenic, vitellogenic and mature ovaries of wild intact and eyestalk-ablated broodstock; $N=6$ for each group). Eighteen cDNA-AFLP fragments were cloned and sequenced. Nucleotide sequences of ten fragments significantly matched $E F-1 \alpha$ (7e63), DEAD box ATP-dependent RNA helicase 48 (PmDdx48; 8e-61), tyrosine phosphatase $n 9$ (1e-42), autophagy related protein Atg4-like protein (3e-36), nuclear pore complex protein nup154 (6e-20), GK14382 gene product (1e-20), L-3-hydroxyacryl coenzyme A dehydrogenase short chain (8e-13) and three different hypothetical proteins. The remaining fragments did not match any previously deposited sequence (E-value $>10-4)$. The full-length cDNA of $P m D d x 48$ was successfully characterized. It was 1646 bp containing an open reading frame (ORF) of 1209 bp corresponding to 402 amino acids. $P m D d x 48$ was up-regulated in late vitellogenic and mature ovaries of wild intact broodstock and in mature ovaries of wild eyestalk-ablated broodstock $(P<0.05)$. Unilateral eyestalk ablation resulted in down-regulation of $P m D d x 48$ in late vitellogenic and mature ovaries compared to that of wild intact broodstock $(P<0.05)$.
\end{abstract}

\section{Introduction}

Breeding of pond-reared giant tiger shrimp (Penaeus monodon) is rather difficult due to reduced degrees of reproductive maturation of females in captivity (Withyachumnarnkul et al., 1998; Coman et al., 2006). This crucially prohibits the development of effective selective breeding programs of this species. Eyestalk ablation was practically applied for stimulation of ovarian maturation in female penaeid shrimp (Benzie, 1998; Brody, 1998). Nevertheless, an issue on the animal welfare on this approach leads to the requirement of an alternative technique to the control of reproductive maturation without eyestalk ablation (Brody, 1998).

Genetic improvement of $P$. monodon cannot be achieved without knowledge on the control of reproduction. The basic knowledge on molecular mechanisms controlling ovarian development and maturation of $P$. monodon is important and can be directly applied to the shrimp industry (Quackenbush, 2001; Preechaphol et al., 2010). Therefore, identification and characterization of differentially expressed genes during ovarian development of this species is necessary.

Previously, differentially expressed transcripts of reproduction-related genes in ovaries of $P$. monodon were examined using typical EST analysis of vitellogenic ovaries (Tassanakajon et al., 2006; Prechaphol et al., 2007), subtraction subtractive hybridization (SSH) between cDNAs in stages I (previtellogenic) and III (late vitellogenic) (Leelatanawit et al., 2004) and 454 pyrosequencing of those in stages I and IV (mature) 
ovaries (Uengwetwanit et al., 2018). Many reproduction-related transcripts were identified. However, isolation of differentially expressed genes involving ovarian (and oocyte) development of $P$. monodon using a simple method like complementary DNA-amplified fragment length polymorphism (cDNAAFLP) has not been reported.

The cDNA-AFLP was derived from a typical AFLP analysis (Vos et al., 1995). It is a rapid technique for screening of differentially expressed transcripts which does not require any prior knowledge of gene sequences. In this study, we used cDNA-AFLP to isolate transcripts differentially expressed during ovarian development of $P$. monodon. The full-length cDNA of DEAD box ATP-dependent RNA helicase 48 (PmDdx48) was further characterized and reported for the first time in this commercially important species. The expression profile of $P m D d x 48$ was examined in different ovarian developmental stages using quantitative real-time PCR.

\section{Materials and Methods}

\section{Experimental Animals and Design}

For cDNA-AFLP analysis, 5-month-old juveniles were collected from Shrimp Genetic Improvement Center (SGIC), Surat Thani located in Southern Thailand $(N=6)$. In addition, wild broodstock were collected from the Andaman Sea and acclimated in the laboratory conditions for 7 days. For the eyestalk ablation group, wild shrimp were unilateral eyestalk-ablated. Ovaries were dissected out from cultured juveniles $(N=6)$ and wild intact and eyestalk-ablated broodstock and weighed. The ovarian developmental stage of juveniles was regarded as premature ovaries while those of broodstock were classified into different stages according to gonadosomatic indices (GSI, ovarian weight/body weight $\times 100$ ): $<2, \quad 2-4$ and $>6 \%$ for previtellogenetic (stage I), vitellogenetic (stage II) and mature (stage IV) ovaries ( $N=6$ for each stage), respectively.

For determination of the expression level of PmDdx48 during ovarian development, female broodstock of $P$. monodon were live-caught from the Andaman Sea and acclimated under the farm conditions for 7 days. Intact and eyestalk-ablated broodstock were prepared as described above. Ovarian developmental stages were classified by GSI and further confirm by conventional histology and divided to previtellogenic (stage I, $N=10$ and 4 for normal and eyestalk-ablated broodstock, respectively), vitellogenic (stage II, $N=7$ and 7), late vitellogenic (stage III, $N=7$ and 10) and mature (stage IV, $N=10$ and 11 ) ovaries, respectively. In addition, juvenile (approximately 5-month-old) shrimp were purchased from a commercial farm and included in the gene expression analysis.

For tissue distribution analysis, various tissues of wild intact females and testes of intact males ( $N=5$ for each sex) were collected. Shrimp tissues were immediately placed in liquid $\mathrm{N}_{2}$ and kept at $-80{ }^{\circ} \mathrm{C}$ until needed.

\section{Total RNA and First-Strand cDNA Synthesis}

Total RNA was extracted from ovaries and other tissues of $P$. monodon using TRI-Reagent (Molecular Research Center). The concentration of extracted total RNA was spectrophotometrically measured. One microgram of DNase I-treated total RNA $(0.5 \mathrm{U} / \mu \mathrm{g}$ of total RNA at $37^{\circ} \mathrm{C}$ for $30 \mathrm{~min}$ ) was reverse-transcribed using an Improm-II ${ }^{\mathrm{TM}}$ Reverse Transcription System (Promega).

\section{Preparation of cDNA-AFLP Template and Analysis}

Messenger (m) RNA was further purified from ovarian total RNA of juvenile and wild broodstock (stages I, II and IV of intact and eyestalk-ablated shrimp; $N=3$ for each stage in duplicate) using an Illustra ${ }^{\mathrm{TM}}$ QuickPrep Micro mRNA Purification Kit (GE Healthcare). One microgram of mRNA was reverse-transcribed to the first-strand cDNA by combined with 3' SMART ${ }^{\mathrm{TM}}$ CDS Primer II A (5'AAGCAGTGGTATCAACGCAGAGTACT-3', $15 \mu \mathrm{M}$ final concentration), SMART II ${ }^{\mathrm{TM}} \mathrm{A}$ Oligonucleotide (5'AAGCAGTGGTATCAACGCAGAGTACGCGGG-3', $15 \mu \mathrm{M}$ final concentration). The reaction was incubated at $72 \circ \mathrm{C}$ for $2 \mathrm{~min}$ and cooled on ice for $5 \mathrm{~min}$ and $5 X$ First-Strand Buffer; dithiothreitol (DTT), dNTPs and BD Powerscript ${ }^{\mathrm{TM}}$ Reverse Transcriptase (Clontech) were added and gently mixed to the final concentrations of $1 \mathrm{X}, 2 \mathrm{mM}$ and $1 \mathrm{mM}$, respectively. The reaction mixture was incubated at $42^{\circ} \mathrm{C}$ for $1.5 \mathrm{~h}$. Two microliters of the reversetranscribed product were subjected to the secondstranded cDNA synthesis by PCR. The reaction components $(50 \mu \mathrm{l})$ containing $1 \mathrm{X}$ Advantage $2 \mathrm{PCR}$ Buffer, $0.2 \mathrm{mM}$ of each dNTP, $0.6 \mu \mathrm{M}$ 5' PCR Primer II A (5'-AAGCAGTGGTATCAACGCAGAGT-3') and $1 \mathrm{X}$ BD Advantage 2 Polymerase Mix (Clontech), respectively. The reaction mixture was incubated at 95으 1 for $1 \mathrm{~min}$ followed by $95^{\circ} \mathrm{C}$ for $15 \mathrm{~s}, 65^{\circ} \mathrm{C}$ for $30 \mathrm{~s}$ and $68^{\circ} \mathrm{C}$ for 6 min for 3, 5 and 7 cycles. The synthesized cDNA ( 3 cycles) was purified by a phenol-chloroform extraction method. The cDNA was ethanol-precipitated and resuspended in $10 \mu$ of TE buffer ( $10 \mathrm{mM}$ Tris- $\mathrm{HCl}$ and $0.1 \mathrm{mM}$ EDTA, $\mathrm{pH}$ 8.0). One microgram of the synthesized CDNA was digested with 6 units of Eco RI and Mse I (Vos et al., 1995). The digested cDNA was ligated with restriction site-specific adaptors. Preamplification was carried out utilizing adaptor specific primers with no selective base; E (5'-GACTGCGTACCAATTC-3') and $\mathrm{M}$ (5'GATGAGTCCTGAGTAA-3') or a single selective base on the $3^{\prime}$ terminus of each primer; $E_{+A}$ (5'GACTGCGTACCAATTCA- $\left.3^{\prime}\right)$ and $M+c$ (5'GATGAGTCCTGAGTAAC $\left.-3^{\prime}\right)$. The preamplification product was diluted 25 -fold, and selectively amplified with primers with additional 2 selective bases at the 3 ' terminus of each primer $\left(E_{+N N}\right.$ and $M_{+N N}$ or $E_{+A N N}$ and $\left.M_{+C N N}\right)$. The cDNA-AFLP fragments were size- 
fractionated through $5 \%$ denaturing polyacrylamide sequencing gels and visualized by silver staining (Sambrook \& Russell, 2001).

\section{Cloning of Differentially Expressed cDNA-AFLP Fragment}

A CDNA-AFLP band was excised from polyacrylamide gel, placed a sterile microcentrifuge tube containing $100 \mu \mathrm{l}$ sterile deionized water and incubated at $60^{\circ} \mathrm{C}$ for $1 \mathrm{~h}$. The eluted DNA fragment was re-amplified by PCR. The resulting product was ligated to the PGEM ${ }^{\circledR}$-T Easy Vector (Promega) in a $10 \mu \mathrm{l}$ reaction volume containing $5 \mu \mathrm{l}$ of $2 x$ Rapid Ligation Buffer (60 mM Tris- $\mathrm{HCl}, \mathrm{pH} 7.8,20 \mathrm{mM} \mathrm{MgCl}, 20 \mathrm{mM}$ DDT, 2 mM ATP and 10\% PEG8000), 25 ng of the PGEM ${ }^{\circ}$ T Easy vector, 3 unit of T4 DNA ligase and 1-3 $\mu$ I DNA insert. The ligation mixture was incubated overnight at $16^{\circ} \mathrm{C}$ before transformation into E. coli JM 109 (Sambrook \& Russell, 2001). Plasmid DNA was extracted and sequenced for both directions using an automated DNA sequencer.

\section{Rapid Amplification of cDNA End-Polymerase chain reaction (RACE-PCR) of PmDdx48}

Gene specific primers for 5'RACE-PCR (R: 5'GTCAGCCAGTCCACCTTACG-3') and 3'RACE-PCR (F: 5'TACCGTTACCTTCCACCAGC-3') of PmDdx48 were designed. RACE-PCR was carried out using a SMART RACE cDNA Amplification Kit following the protocol recommended by the manufacturer (BD Bioscience Clontech). The amplified fragment was electrophoretically analyzed, eluted from the gel, cloned into pGEM-T Easy vector and sequenced. Nucleotide sequences of EST and RACE fragments were assembled and searched against previously deposited sequences in GenBank using Blast $X$ (Altschul et al., 1990). The $p /$ value and molecular mass of the deduced $P$. monodon Ddx48 (PmDdx48) protein were examined using ProtParam (http://www.expasy.org/tools/protparam.html). The protein domain and signal peptide in the deduced PmDdx48 protein were predicted using SMART (http://smart.embl-heidelberg.de).

\section{Quantitative Real-Time PCR}

Expression of PmDdx48 in different tissues of wild intact females and different ovarian developmental stages of wild intact and eyestalk-ablated $P$. monodon was examined using quantitative real-time PCR. Standard curves representing $10^{3}-10^{8}$ copies of recombinant plasmids of the target genes $(P m D d x 48)$ and the reference gene $\left(E F-1 \alpha_{214}\right)$ were constructed The expression level of PmDdx48 (F: 5'TACCGTTACCTTCCACCAGC-3' and R: 5'GTCAGCCAGTCCACCTTACG-3') and EF-1 $\alpha_{214}$ (F: 5'GTCTTCCCCTTCAGGACGTC-3' and R: $3^{\prime}$ CTTTACAGACACGTTCTTCACGTTG-3') in ovaries of each shrimp were amplified in a $10 \mu$ reaction volume contained $5 \mu$ l of $2 x$ LightCycler 480 SYBR Green I Master (Roche), $50(P m D d x 48)$ or $5 \mathrm{ng}\left(E F-1 \alpha_{214}\right)$ of the firststrand cDNA template, $0.3 \mu \mathrm{M}$ each of gene-specific primers. The thermal profile for quantitative real-time PCR was $95^{\circ} \mathrm{C}$ for 10 min followed by 40 cycles of $95^{\circ} \mathrm{C}$ for $30 \mathrm{~s}, 58^{\circ} \mathrm{C}$ for $30 \mathrm{~s}$ and $72^{\circ} \mathrm{C}$ for $30 \mathrm{~s}$. The specificity of PCR products was confirmed by melting curve analysis performed at $95^{\circ} \mathrm{C}$ for $15 \mathrm{~s}, 65^{\circ} \mathrm{C}$ for $1 \mathrm{~min}$ and $98^{\circ} \mathrm{C}$ for a continuous fluorescent reading (ramp time $=0.11$ o $\mathrm{C} / \mathrm{s}$ ). The cooling process was carried out at $40^{\circ} \mathrm{C}$ for 30 s. Quantitative real-time PCR of each specimen was carried out in duplicate. The relative expression level (copy number of PmDdx48 and that of EF-1 $\alpha$ ) between shrimp possessing different stages of ovarian development were statistically tested using one way analysis of variance (ANOVA) followed by Duncan's new multiple range test. Significant differences between groups of samples were considered when $\mathrm{P}<0.05$.

\section{Results and Discussion}

\section{Isolation of Differentially Expressed Transcripts in} Ovaries of $\boldsymbol{P}$. monodon

Analysis of differentially expressed transcripts provides the basic information required for further analysis of molecular reproduction in $P$. monodon. In this study, cDNA-AFLP analysis was applied for identification of differentially expressed transcripts in ovaries of $P$. monodon. This method is highly versatile in that both up-regulated and down-regulated genes can be identified by visualization of side-by-side comparisons using various primer combinations.

Initially, the first-strand cDNA was reversetranscribed from mRNA of $P$. monodon having different ovarian developmental stages. The second-strand cDNA was synthesized by long distance PCR for 3, 5 and 7 cycles. Smear amplification products were observed in all samples and products from the lowest amplification cycle was chosen for further study (data not shown).

A total of 75 primer combinations were screened. Thirty-five primer combinations yielded positive amplification products were further analyzed by denaturing polyacrylamide gel electrophoresis. Ninetytwo cDNA-AFLP fragments showed differential expression between groups of samples (Table 1). The expression patterns of cDNA-AFLP fragments were classified to 5 different groups; those only expressed in juveniles, those preferentially expressed in juvenile than broodstock ovaries and vice versa and those preferentially expressed in ovaries of intact- than eyestalk-ablated broodstock and vice versa, respectively (Table 1).

In the Pacific oyster (Crassostrea gigas), cDNAAFLP was applied for identifying genes differentially expressed in response to Vibrio tubiashii exposure or between different families. In total, 92 fragments were found from 32 primer combinations. Fourteen cDNA- 
Table 1. Candidate differential expressed CDNA-AFLP fragments in ovaries of $P$. monodon

\begin{tabular}{|c|c|c|c|c|c|}
\hline \multirow[t]{2}{*}{ Primer } & \multicolumn{5}{|c|}{ Expression pattern } \\
\hline & Juveniles only & $\begin{array}{l}\text { Juveniles }> \\
\text { broostock }\end{array}$ & $\begin{array}{c}\text { Broostock }> \\
\text { juveniles }\end{array}$ & $\begin{array}{l}\text { Intact > eyestalk- } \\
\text { ablated broodstock }\end{array}$ & $\begin{array}{l}\text { Eyestalk-ablated > } \\
\text { intact broodstock }\end{array}$ \\
\hline $\mathrm{E}_{\mathrm{ACA}} / \mathrm{M}_{\mathrm{CAC}}$ & - & 318 & - & - & - \\
\hline $\mathrm{E}_{\mathrm{ACT}} / \mathrm{M}_{\mathrm{CAA}}$ & - & - & - & 366,570 & - \\
\hline $\mathrm{E}_{\mathrm{TA}} / \mathrm{M}_{\mathrm{AA}}$ & 460 & - & - & - & $292,387,400$ \\
\hline $\mathrm{E}_{\mathrm{TA}} / \mathrm{M}_{\mathrm{TG}}$ & - & - & - & - & - \\
\hline $\mathrm{E}_{\mathrm{TA}} / \mathrm{M}_{\mathrm{GG}}$ & - & - & - & - & 381 \\
\hline $\mathrm{E}_{\mathrm{TT}} / \mathrm{M}_{\mathrm{AG}}$ & - & - & - & 750 & - \\
\hline $\mathrm{E}_{\mathrm{TT}} / \mathrm{M}_{\mathrm{TC}}$ & 600 & - & - & $404^{*}$ & - \\
\hline $\mathrm{E}_{\mathrm{TT}} / \mathrm{M}_{\mathrm{TG}}$ & - & 285,374 & - & - & 503 \\
\hline $\mathrm{E}_{T T} / \mathrm{M}_{\mathrm{GA}}$ & - & 350,456 & - & - & - \\
\hline $\mathrm{E}_{\mathrm{TT}} / \mathrm{M}_{\mathrm{GT}}$ & 700 & - & - & 435 & 338 \\
\hline $\mathrm{E}_{\mathrm{TT}} / \mathrm{M}_{\mathrm{GG}}$ & 680 & 580,780 & - & - & - \\
\hline $\mathrm{E}_{\mathrm{TG}} / \mathrm{M}_{\mathrm{AA}}$ & - & - & - & - & 462,511 \\
\hline $\mathrm{E}_{\mathrm{TG}} / \mathrm{M}_{\mathrm{AT}}$ & - & 413 & - & - & 539,560 \\
\hline $\mathrm{E}_{\mathrm{TG}} / \mathrm{M}_{\mathrm{AG}}$ & - & $380,520,620$ & - & - & - \\
\hline $\mathrm{E}_{\mathrm{TG}} / \mathrm{M}_{\mathrm{TT}}$ & - & - & 680 & - & 500,1000 \\
\hline $\mathrm{E}_{\mathrm{GA}} / \mathrm{M}_{\mathrm{AA}}$ & - & - & - & - & 560,580 \\
\hline $\mathrm{E}_{\mathrm{GA}} / \mathrm{M}_{\mathrm{AG}}$ & - & - & 900 & - & $320,400,450$ \\
\hline $\mathrm{E}_{\mathrm{GA}} / \mathrm{M}_{\mathrm{TC}}$ & - & - & - & - & $880,900,1000$ \\
\hline $\mathrm{E}_{\mathrm{GA}} / \mathrm{M}_{\mathrm{TG}}$ & - & - & - & - & 950 \\
\hline $\mathrm{E}_{\mathrm{GA}} / \mathrm{M}_{\mathrm{GA}}$ & - & - & - & - & $\begin{array}{c}380,400,480,550 \\
620900,1000\end{array}$ \\
\hline $\mathrm{E}_{\mathrm{GA}} / \mathrm{M}_{\mathrm{GT}}$ & 380,850 & 400 & - & 500 & 900,1000 \\
\hline $\mathrm{E}_{\mathrm{GA}} / \mathrm{M}_{\mathrm{GG}}$ & 500 & - & - & - & $400,550,980$ \\
\hline $\mathrm{E}_{\mathrm{GT}} / \mathrm{M}_{\mathrm{TA}}$ & 350 & - & - & - & $\begin{array}{c}360,380,500,680 \\
720,900\end{array}$ \\
\hline $\mathrm{E}_{\mathrm{GT}} / \mathrm{M}_{\mathrm{TT}}$ & - & - & - & - & 500 \\
\hline $\mathrm{E}_{\mathrm{GT}} / \mathrm{M}_{\mathrm{TC}}$ & - & - & - & - & - \\
\hline $\mathrm{E}_{\mathrm{GT}} / \mathrm{M}_{\mathrm{TG}}$ & - & - & - & 420 & 300 \\
\hline $\mathrm{E}_{\mathrm{GT}} / \mathrm{M}_{\mathrm{GA}}$ & - & - & - & - & 580 \\
\hline $\mathrm{E}_{\mathrm{GT}} / \mathrm{M}_{\mathrm{GT}}$ & - & - & - & 340 & 360,480 \\
\hline $\mathrm{E}_{\mathrm{GT}} / \mathrm{M}_{\mathrm{GG}}$ & 650 & - & - & - & 480,490 \\
\hline $\mathrm{E}_{\mathrm{GG}} / \mathrm{M}_{\mathrm{AG}}$ & - & 450 & - & 340 & 380,400 \\
\hline $\mathrm{E}_{\mathrm{GG}} / \mathrm{M}_{\mathrm{TA}}$ & - & - & $350,480,700$ & - & - \\
\hline $\mathrm{E}_{\mathrm{GG}} / \mathrm{M}_{\mathrm{TC}}$ & - & - & - & - & - \\
\hline $\mathrm{E}_{\mathrm{GG}} / \mathrm{M}_{\mathrm{TG}}$ & - & - & - & & - \\
\hline $\mathrm{E}_{\mathrm{GG}} / \mathrm{M}_{\mathrm{GA}}$ & - & - & 400 & 320 & 500,550 \\
\hline $\mathrm{E}_{\mathrm{GG}} / \mathrm{M}_{\mathrm{GT}}$ & 900 & 620 & 380,460 & & \\
\hline
\end{tabular}

Fragment that were cloned and sequenced were boldfaced. * = fragments that was applied for gene expression analysis using qRT-PCR.

AFLP fragments were cloned and sequenced. Genes involved in immune response and metabolic processes and their expression levels were characterized. Most of the differences in transcription patterns between stresstolerant and stress-sensitive families were found following bacterial exposure (Taris et al., 2009).

Likewise, a large number of differentially expressed cDNA-AFLP fragments were found in the present study. Eighteen cDNA-AFLP fragments including one cDNA-AFLP fragments found only in juveniles, five fragments which were more preferentially expressed in juveniles than broodstock, four fragments displaying a greater expression in wild intact than eyestalk-ablated broodstock and eight fragments showing a greater expression in wild eyestalk-ablated than intact broodstock were cloned and sequenced (Table 1).

Nucleotide sequences of ten fragments were significantly matched elongation factor-1 alpha of $P$. monodon (E-value = 7e-63), DEAD box ATP-dependent RNA helicase 48 of Aedes aegypti (Ddx48; $E$-value $=8 \mathrm{e}$ -
61), tyrosine phosphatase n9 of Culex quinquefasciatus $(E$-value $=1 \mathrm{e}-42)$, autophagy related protein Atg4-like protein of Bombyx mori (E-value $=3 e-36)$, hypothetical protein of Branchiostoma floridae (E-value $=3 \mathrm{e}-27)$, hypothetical protein CBG10789 of Caenorhabditis briggsae AF16 (E-value $=5 \mathrm{e}-24)$, hypothetical protein LOC100125170 of Xenopus tropacalis ( $E$-value $=2 \mathrm{e}-24)$, nuclear pore complex protein nup154 of Nasonia vitripennis (E-value $=6 \mathrm{e}-20)$, GK14382 gene product from transcript GK14382-RA of Drosophila willistoni ( $E$ value $=1 \mathrm{e}-20), \quad$ L-3-hydroxyacryl coenzyme $A$ dehydrogenase short chain of Ciona intestinalis ( $E$-value = 8e-13) (Table 2). In contrast, those of eight cDNA-AFLP fragments did not match previously deposited sequences in GenBank ( $E$-value > 10e-4) (Table 2).

DEAD box proteins are putative ATP-dependent RNA unwinding proteins whose primary biochemical function is the alteration of RNA secondary structure. They have been implicated in translation initiation, ribosome assembly, RNA splicing, and RNA stability 
Table 2. Similarity analysis of candidate differentially expressed cDNA-AFLP fragments in ovaries of $P$. monodon

\begin{tabular}{|c|c|c|c|}
\hline Fragment & Closest similarity & Species & $E$-value \\
\hline $\mathrm{E}_{\mathrm{ACT}} / \mathrm{M}_{\mathrm{CAA}-366}$ & $\begin{array}{c}\text { L-3-hydroxyacryl coenzyme A dehydrogenase short } \\
\text { chain }\end{array}$ & Ciona intestinalis & $8 e-13$ \\
\hline $\mathrm{E}_{\mathrm{TA}} / \mathrm{M}_{\mathrm{GG}}-381$ & Elongation factor-1 alpha & Penaeus monodon & $7 e-63$ \\
\hline $\mathrm{E}_{\mathrm{TT}} / \mathrm{M}_{\mathrm{TC}}-404$ & DEAD box ATP-dependent RNA helicase 48 & Aedes aegypti & $8 e-61$ \\
\hline $\mathrm{E}_{\mathrm{TT}} / \mathrm{M}_{\mathrm{TG}}-374$ & Tyrosine phosphatase $n g$ & Culex quinquefasciatus & $1 e-42$ \\
\hline $\mathrm{E}_{T T} / \mathrm{M}_{\mathrm{GA}}-456$ & Nuclear pore complex protein nup154 & Nasonia vitripennis & $6 e-20$ \\
\hline $\mathrm{E}_{\mathrm{TG}} / \mathrm{M}_{\mathrm{AA}}-462$ & GK14382 gene product & Drosophila willistoni & $1 e-20$ \\
\hline $\mathrm{E}_{\mathrm{TG}} / \mathrm{M}_{\mathrm{AT}}-413$ & Autophagy related protein Atg4-like protein & Bombyx mori & $3 e-36$ \\
\hline $\mathrm{E}_{\mathrm{TA}} / \mathrm{M}_{\mathrm{AA}}-292$ & Hypothetical protein CBG10789 AF16 & Caenorhabditis briggsae & $5 e-24$ \\
\hline $\mathrm{E}_{\mathrm{TG}} / \mathrm{M}_{\mathrm{AT}}-539$ & Hypothetical protein LOC100125170 & Xenopus tropicalis & $2 e-24$ \\
\hline $\mathrm{E}_{T T} / \mathrm{M}_{\mathrm{GT}}-338$ & Hypothetical protein & Branchiostoma floridae & $3 e-27$ \\
\hline $\mathrm{E}_{\mathrm{ACA}} / \mathrm{M}_{\mathrm{CAC}-}-318$ & Unknown & - & $>1 \mathrm{e}-04$ \\
\hline $\mathrm{E}_{\mathrm{ACT}} / \mathrm{M} 1_{\mathrm{CAA}}-570$ & Unknown & - & $>1 \mathrm{e}-04$ \\
\hline $\mathrm{E}_{\mathrm{TA}} / \mathrm{M}_{\mathrm{AA}}-387$ & Unknown & - & $>1 \mathrm{e}-04$ \\
\hline $\mathrm{E}_{\mathrm{TA}} / \mathrm{M}_{\mathrm{AA}}-460$ & Unknown & - & $>1 \mathrm{e}-04$ \\
\hline $\mathrm{E}_{\mathrm{TG}} / \mathrm{M}_{\mathrm{AA}}-511$ & Unknown & - & $>1 \mathrm{e}-04$ \\
\hline $\mathrm{E}_{\mathrm{TT}} / \mathrm{M}_{\mathrm{TG}}-285$ & Unknown & - & $>1 \mathrm{e}-04$ \\
\hline $\mathrm{E}_{\mathrm{TT}} / \mathrm{M}_{\mathrm{TG}}-503$ & Unknown & - & $>1 \mathrm{e}-04$ \\
\hline $\mathrm{E}_{\mathrm{TT}} / \mathrm{M}_{\mathrm{GT}}-435$ & Unknown & - & $>1 \mathrm{e}-04$ \\
\hline
\end{tabular}

(Cordin et al., 2006; Cesar Lopez et al., 2008). DEAD-box RNA helicases are required for germ cell functions (Cordin et al., 2006). Some members of this family are believed to be involved in embryogenesis, spermatogenesis, and cellular growth and division. In Drosophila melanogaster, a null Ddx1 mutation flies are smaller than the normal and heterozygous flies. Female $D d x 1$ null flies have reduced fertility with egg chambers undergoing autophagy, whereas males are sterile due to disrupted spermatogenesis (Germain et al., 2015).

The vasa gene, which encodes an ATP-dependent RNA helicase belonging to the DEAD-box protein family, was identified in the Pacific white shrimp, Litopenaeus vannamei (Alfalo et al., 2007), Chinese shrimp, Fenneropenaeus chinensis (Zhou et al., 2010) and the giant freshwater prawn, Macrobrachium rosenbergii (Nakkrasae \& Damrongphol, 2007). Vasa was only expressed in gonads of adults of these species and was proposed to be a potential biomarker for germ cell development. In Drosophila, mutations in vasa may cause sterility in females with severe defects in oogenesis. Less damaging mutations were also found where oogenesis allows to proceed but the eggs develop into embryos lacking primordial germ cells (PGCs) (Hay et al., 1988; Lasko et al., 1988).

The partial cDNA sequence of $P m D d x 48$ has been identified from EST analysis of $P$. monodon from both conventional and SSH libraries (Preechaphol et al., 2007 and 2010). However, data on isolation and characterization of this DEAD-box protein gene and its expression profiles during ovarian development of $P$. monodon has not been reported.

\section{Isolation and Characterization of the Full-Length cDNA of PmDdx48}

In this study, RACE-PCR was carried out and discrete bands of $900 \mathrm{bp}$ and $1000 \mathrm{bp}$ fragments were obtained from $5^{\prime}$ and $3^{\prime}$ RACE-PCR of PmDdx48. Nucleotide sequences of RACE-PCR fragments were assembled with that of the cDNA-AFLP clone. The fulllength cDNA of PmDdx48 were successfully characterized and reported for the first time in $P$. monodon. It was 1646 bp in length containing an ORF of $1209 \mathrm{bp}$ corresponding to a polypeptide of 402 amino acids with $5^{\prime}$ and $3^{\prime}$ UTRs of 53 and 418 bp long (excluding the poly $A$ tail), respectively (GenBank accession no. KY982623, Figure 1). Its closest similar sequence was Ddx48 (also called eukaryotic initiation factor $4 A$-III) of Zootermopsis nevadensis ( $E$-value $=0.0$ and identity $=93 \%$ ). The calculated $\mathrm{p} /$ and molecular mass of $P m D d x 48$ was 5.91 and $46.11 \mathrm{kDa}$, respectively. The predicted signal peptide was not found in the deduced PmDdx48 protein. DEXDc and HELICc domains were found at positions $48-245$ ( $E$-value $=3.84 \mathrm{e}-55)$ and $282-363(E$-value $=1.07 \mathrm{e}-35)$ of the deduced PmDdx48 protein, respectively. The conserved motif, (V/I)-L-D-E-AD- X-(M/L)-L-X-X-G-F, observed in all members of the DEAD box protein family (Linder et al., 1989; Tanner and Linder, 2001) was also found in PmDdx48.

\section{Tissue Expression Analysis of PmDdx48}

Gene expression and tissue distribution analysis are important and provide the basic information for further analysis of functionally important genes (Klinbunga et al., 2009). Based on the fact that a particular gene may express in several tissues and possesses different functions in different tissues. PmDdx48 was abundantly expressed in subcuticular epithelium and thoracic ganglion followed by eyestalk. It was comparably expressed in ovaries, testes, and other tissues (hemocytes, heart, pleopod, gill, lymphoid organ, intestine, hepatopancreas and stomach; Figure 2). This suggested that $P m D d x 48$ should be a 


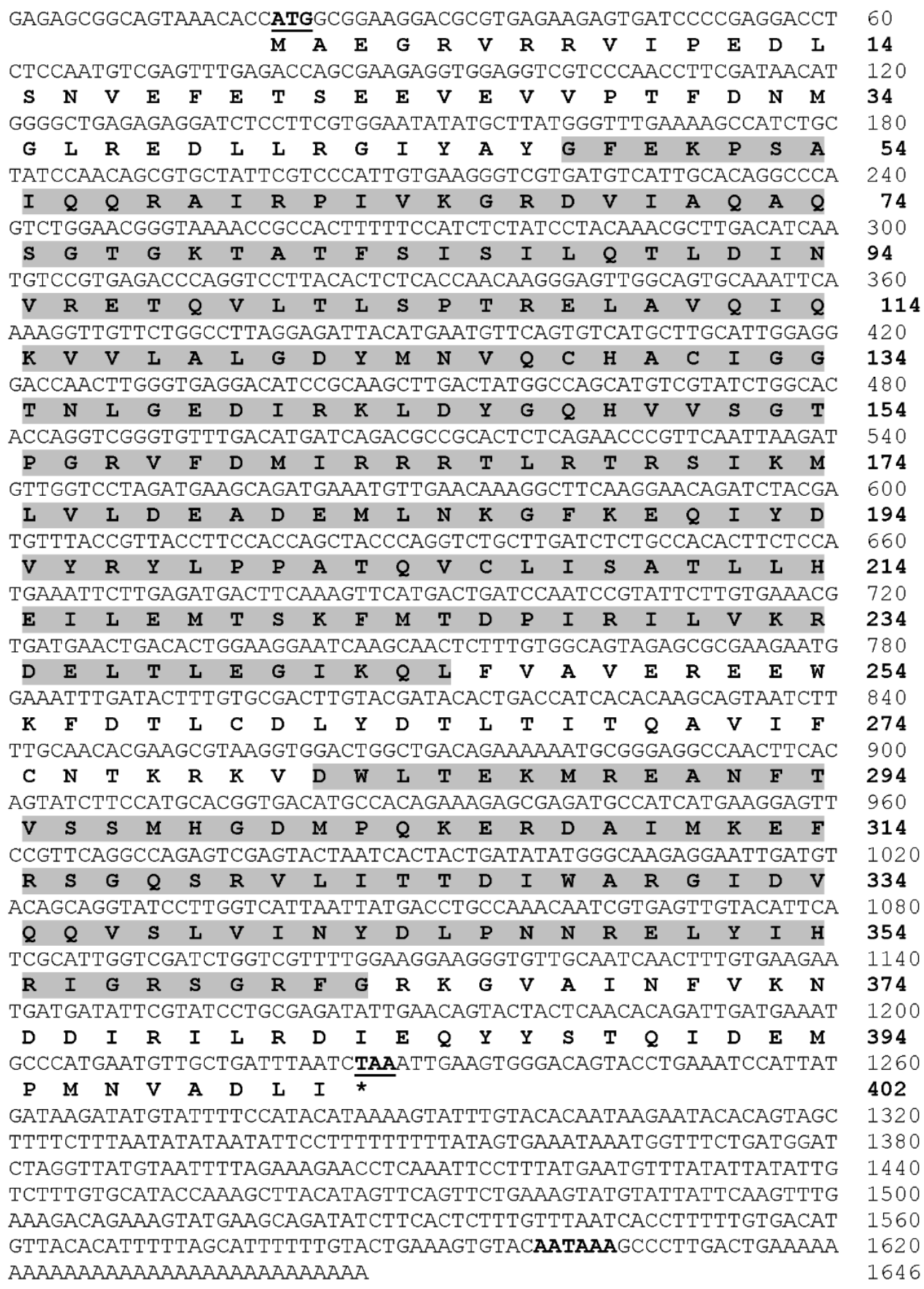

Figure 1. The full-length CDNA and deduced protein sequences of DEAD box ATP-dependent RNA helicase of $P$. monodon (PmDdx48). Start and stop codons are illustrated in boldfaced and underlined. The poly A additional signal (AATAAA) is boldfaced. Predicted DEXDC (amino acid positions 48-245) and HELICC (282-363) domains are highlighted.

multifunctional protein playing different functions in various tissues of $P$. monodon.

\section{Expression Levels of PmDdx48 During Ovarian Development of Wild $P$. monodon Broodstock}

Transcripts preferentially expressed in different stages of ovarian development can be used as the responsive indicators for reproductive maturation of $P$. monodon. The expression level of $P m D d x 48$ in ovaries of cultured juveniles was not significantly different from stage I (previtellogenic) ovaries of wild broodstock $(P>0.05)$ but significantly lower than that of subsequent ovarian stages of wild intact adults $(P<0.05)$. This critically implied that $P m D d x 48$ is functionally involved in ovarian development of $P$. monodon.

In wild intact broodstock, the PmDdx48 transcript was up-regulated in stages III (late vitellogenic) and IV (mature) ovaries $(P<0.05)$. Its expression level was then decreased at the post-spawning stage $(P<0.05)$. In eyestalk-ablated broodstock, $P m D d x 48$ was upregulated in stages IV ovaries $(P<0.05)$. The expression 


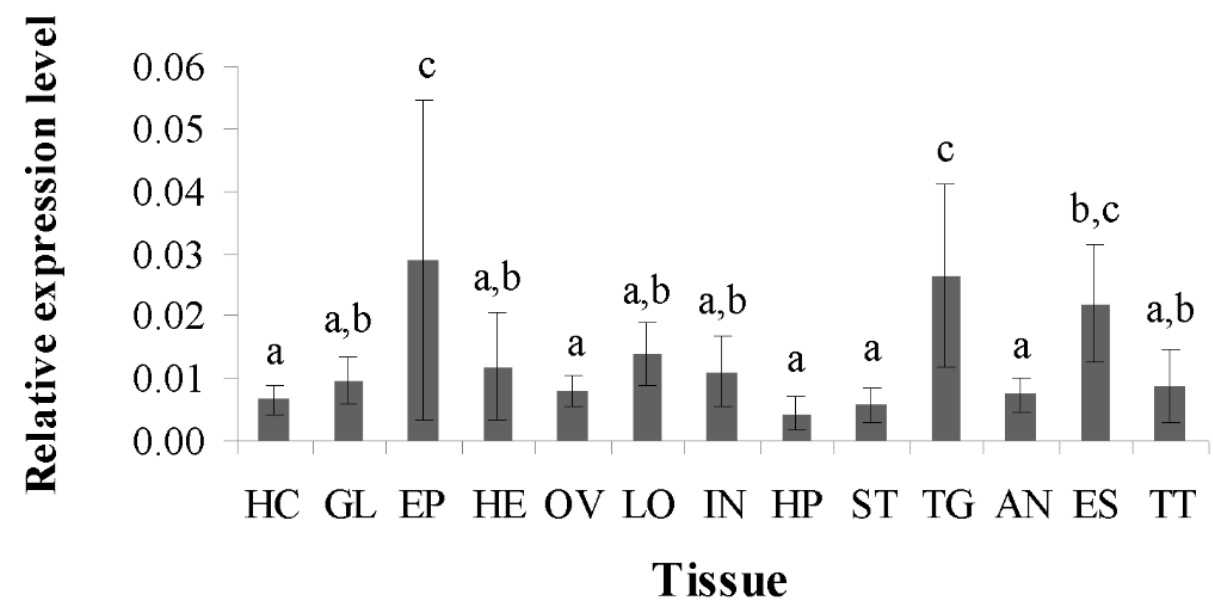

Figure 2. Histograms showing relative expression levels of $P m D d x 48$ in various tissues of wild intact female broodstock and testes of male broodstock of $P$. monodon. $\mathrm{HC}=$ hemocytes, $\mathrm{GL}=$ gill, $\mathrm{EP}=$ subcuticular epithelium, $\mathrm{HE}=$ heart, $\mathrm{OV}=$ ovaries, $\mathrm{LO}=\mathrm{lymphoid}$ organs, IN = intestine, $\mathrm{HP}=$ hepatopancreas, $\mathrm{ST}=$ stomach, $\mathrm{TG}=$ thoracic ganglion, $\mathrm{AN}=$ antennal gland, $\mathrm{ES}=$ eyestalk and TT = testes. Bars indicate mean relative expression levels \pm standard deviation (SD) for PmDdx48 mRNA. Different letters above bars indicate significant differences between relative expression levels of different tissues.

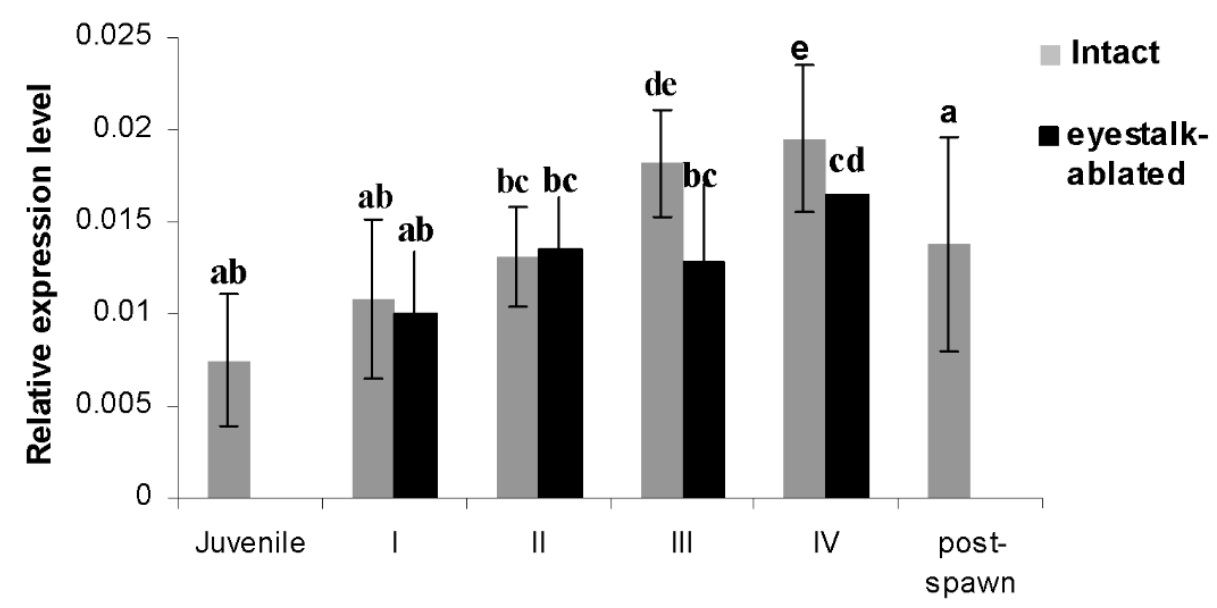

\section{Ovarian development stages}

Figure 3. Histograms showing relative expression levels of $P m D d x 48$ (mean \pm SD) during ovarian development of intact and unilateral eyestalk-ablated $P$. monodon broodstock. Different letters above bars indicate significant differences between relative expression levels of experimental groups of samples.

profiles of PmDdx48 in ovaries of wild intact and eyestalk-ablated broodstock suggested that it plays a functionally role during late vitellogenic and mature stages of ovarian development. Eyestalk-ablation resulted in significant reduction of $P m D d x 48$ in stages III and IV ovaries compared to that of the same stages in intact broodstock (Figure 3). This opens the possible use of RNA interference (RNAi) for induction of ovarian development of $P$. monodon.

In the present study, several reproduction-related transcripts in ovaries of $P$. monodon were identified by cDNA-AFLP analysis. The full-length CDNA and expression profiles of PmDdx48 were examined. The functional involvement of additional genes in ovarian development of $P$. monodon found in the present study should be further studies for better understanding the reproductive maturation of $P$. monodon in captivity.

\section{References}

Aflalo, E. D., Bakhrat, A., Raviv, S., Harari, D., Sagi, A., \& Abdu, U. (2007). Characterization of a vasa-like gene from the pacific white shrimp Litopenaeus vannamei and its expression during oogenesis. Molecular Reproduction \& Development, 74(2), 172-177. https://doi.org/10.1002/mrd.20622

Altschul, S. F., Gish, W., Miller, W., Myers, E. W., \& Lipman, D. J. (1990). Basic local alignment search tool. Journal of Molecular Biology, 215(3), 403-410. https://doi.org/10.1016/S0022-2836(05)80360-2

Benzie, J. A. H. (1998). Penaeid genetics and biotechnology. Aquaculture, 164(1-4), 23-47. https://doi.org/10.1016/S0044-8486(98)00175-6

Brody, C.L. (1998). Recent development in penaeid broodstock and seed production technologies: improving the outlook for superior stock. Aquaculture, 164(1-4), 3-21. 
https://doi.org/10.1016/S0044-8486(98)00174-4

Cesar Lopez, C., Garcia-Hernandez, M. L., Marchat, L. M., LunaArias, J. P., Hernandez de la Cruz, O., Mendoza, L., \& Orozco, E. (2008). Entamoeba histolytica EhDEAD1 is a conserved DEAD-box RNA helicase with ATPase and ATPdependent RNA unwinding activities. Gene, 414(1-2), 1931. https://doi.org/10.1016/j.gene.2008.01.024

Coman, G. J., Arnold, S. J., Peixoto, S., Coman, F. E., Crocos, P. J., \& Preston, N.P. (2006). Reproductive performance of reciprocally crossed wild-caught and tank reared Penaeus monodon broodstock. Aquaculture, 252(2-4), 372-384.

https://doi.org/10.1016/j.aquaculture.2005.07.028

Cordin, O., Banroques, J., Tanner, N. K., \& Linder, P. (2006). The DEAD-box protein family of RNA helicases. Gene, 367, 17-37. https://doi.org/10.1016/j.gene.2005.10.019

Germain, D. R., Matthew, L., Hildebrandt, R., Simmonds, A. J., Hughes, S. C. \& Godbout, R. (2015). Loss of the Drosophila melanogaster DEAD box protein Ddx1 leads to reduced size and aberrant gametogenesis. Developmental Biology, 407(2), 232-245. https://doi.org/10.1016/j.ydbio.2015.09.012

Hay, B., Jan, L.Y., \& Jan, Y. N. (1988). A protein component of Drosophila polar granules is encoded by vasa and has extensive sequence similarity to ATP-dependent helicases. Cell, 55(4), 577-587.

https://doi.org/10.1016/0092-8674(88)90216-4

Klinbunga, S., Sittikankaew, K., Yuvanatemiya, V., Preechaphol, R., Prasertlux, S., Yamano, K., \& Menasveta, P. (2009). Molecular cloning and expression analysis of OvarySpecific Transcript 1 (Pm-OST1) of the giant tiger shrimp Penaeus monodon. Zoological Science, 26(11), 783-790. https://doi.org/10.2108/zsj.26.783

Lasko, P. F., \& Ashburner, M. (1988). The product of the Drosophila gene vasa is very similar to eukaryotic initiation factor-4A. Nature, 335, 611-617. https://doi.org/10.1038/335611a0

Leelatanawit, R., Klinbunga, S., Puanglarp, N., Tassanakajon, A., Jarayabhand, P., Hirono, I., Aoki, T., \& Menasveta, P. (2004). Isolation and characterization of differentially expressed genes in ovaries and testes of the giant tiger shrimp (Penaeus monodon). Marine Biotechnology, 6, S506-S510.

Linder, P., Lasko, P. F., Ashburner, M., Leroy, P., Nielsen, P. J., Nishi, K., Schnier, J., \& Slonimski, P. P. (1989). Birth of the D-E-A-D box. Nature, 337, 121-122. https://doi.org/10.1038/337121a0

Nakkrasae, L., \& Damrongphol, P. (2007). A vasa-like gene in the giant freshwater prawn, Macrobrachium rosenbergii. Molecular Reproduction \& Development, 74(7), 835-842. https://doi.org/10.1002/mrd.20680

Preechaphol, R., Klinbunga, S., Yamano, K., \& Menasveta, P. (2010). Molecular cloning and expression of progestin membrane receptor component 1 (Pgmrc1) of the giant tiger shrimp Penaeus monodon. General and Comparative Endocrinology, 168(3), 440-449. https://doi.org/10.1016/j.ygcen.2010.06.002
Preechaphol, R., Leelatanawit, R., Sittikankeaw, K., Klinbunga, S., Khamnamtong, B., Puanglarp, N., \& Menasveta, P. (2007). Expressed sequence tag analysis for identification and characterization of sex-related genes in the giant tiger shrimp Penaeus monodon. Journal Biochemistry and Molecular Biology, 40(4), 501-510. https://doi.org/10.5483/BMBRep.2007.40.4.501

Quackenbush, L. S. (2001). Yolk synthesis in the marine shrimp, Penaeus vannamei. American Zoologist, 41(3), 458-464. https://www.jstor.org/stable/3884476

Sambrook, J., \& Russell, D. W. (2001). Molecular Cloning: A Laboratory Manual, third ed. Cold Spring Harbor Laboratory Press, New York.

Tanner, K. N., \& Linder, P. (2001). DExD/H box RNA helicases: from generic motors to specific dissociation functions. Molecular Cell, 8, 251-262.

https://doi.org/10.1016/S1097-2765(01)00329-X

Taris, N., Lang, R. P., Reno, P. W., \& Camara, M. D. (2009). Transcriptome response of the Pacific oyster (Crassostrea gigas) to infection with Vibrio tubiashii using CDNA AFLP differential display. Animal Genetics, 40(5), 663-667. https://doi.org/10.1111/j.1365-2052.2009.01894.x

Tassanakajon, A., Klinbunga, S., Paunglarp, N., Rimpanichayakit, V., Udomkit, A., Jitrapakdee, S., Dangtip, K., Pongdara, A., Pongsomboon, S., Supungul, P., Tang, S., Kuphanumart, K., Pichyangkura, R., \& Lursinsap, C. (2006). Penaeus monodon gene discovery project: generation of an EST collection and establishment of a database. Gene, 384, 104-112. https://doi.org/10.1016/j.gene.2006.07.012

Uengwetwanit, T., Ponza, P., Sangsrakru, D., Wichadakul, D., Ingsriswang, S., Leelatanawit, R., Klinbunga, S., Tangphatsornruang, S., \& Karoonuthaisiri, N. (2018). Transcriptome-based discovery of pathways and genes related to reproduction of the black tiger shrimp (Penaeus monodon). Marine Genomics, 37, 67-73. https://doi.org/10.1016/j.margen.2017.08.007

Vos, P., Hogers, R., Bleeker, M., Reijans, M., van de Lee, T., Hornes, M., Frijters, A., Pot, J., Peleman, J., \& Kuiper, M. (1995). AFLP: a new technique for DNA fingerprinting. Nucleic Acids Research, 23(21), 4407-4414. https://doi.org/10.1093/nar/23.21.4407

Withyachumnarnkul, B., Boonsaeng, W., Flegel, T. W., Panyim, S., Wongteerasupaya, C. (1998). Domestication and selective breeding of Penaeus monodon in Thailand. In: T. Felgel (Ed.) Proceedings to the Special Session on Advances in Shrimp Biotechnology, The Fifth Asian Fisheries Forum: International Conference on Fisheries and Food Security Beyond the Year 2000 (pp. 73-77). 1114 November 1998. Chiangmai, Thailand.

Zhou, Q., Shao, M., Qin, Z., Kang, K.Y., \& Zhang, Z. (2010). Cloning, characterization, and expression analysis of the DEAD-box family genes, Fc-vasa and Fc-PL10a, in Chinese shrimp (Fenneropenaeus chinensis). Chinese Journal of Oceanology and Limnology, 28(1), 37-45. DOI: 10.1007/s00343-010-9231-y 